\title{
A new small-leaved species of Baccharis (Compositae-Astereae) from Ecuador
}

\author{
by \\ Jochen Müller \\ Herbarium Haussknecht, Friedrich-Schiller-Universität, Fürstengraben 1, 07737 Jena, Germany. Jochen.Mueller@uni-jena.de
}

\begin{abstract}
Müller, J. 2007. A new small-leaved species of Baccharis (Compositae-Astereae) from Ecuador. Anales Jard. Bot. Madrid 64(2): 191-194.

A new species, Baccharis tenuicapitulata Joch. Müll. from central and southern Ecuador is described and illustrated. The morphological delimitation of the new species against similar species is discussed.
\end{abstract}

Keywords: Baccharis, Compositae, Astereae, Ecuador.

\section{Introduction}

In the Andean countries, especially in open habitats, Baccharis L. is a very common and species-rich genus which is taxonomically difficult due to high species number, small size of taxonomically valuable characters and often great intraspecific variability of more easily recognizable characters (Müller, 2006). These difficulties especially concern small-leaved species of $B$. subgen. Baccharis that includes about one third of all Ecuadorian species. Jørgensen (1999) reported 45 species of Baccharis for mainland Ecuador, 10 of them endemic. Preliminary revisionary study of Ecuadorian Baccharis for a forthcoming Flora of Ecuador treatment (Müller, unpubl. data) suggests that species number is probably somewhat lower (35-40), but number of endemic species higher (ca. 13). Additionally, the Andes of central and southern Ecuador (Prov. Chimborazo-Loja) are the centre of richness of species and endemics within the country.

A species described here is also endemic to that region. It was hitherto frequently determined as Baccharis tricuneata (L. f.) Pers., a species described from Colombia that does not occur in Ecuador. Some specimens of the new species (Maguire 44294, Prieto 210)

\section{Resumen}

Müller, J. 2007. Una nueva especie de hojas pequeñas de Baccharis (Compositae-Astereae) de Ecuador. Anales Jard. Bot. Madrid 64(2): 191-194 (en inglés).

Se describe e ilustra una nueva especie, Baccharis tenuicapitulata Joch. Müll. del centro y sur del Ecuador. Además, se compara la delimitación morfológica de la nueva especie con especies similares.

Palabras clave: Baccharis, Compositae, Astereae, Ecuador.

were referred by Cuatrecasas (1969) to Baccharis variifolia Hieron., which was included by him as a variety in B. tricuneata. However, the specimens placed in B. variifolia by Cuatrecasas (1969) belong to three different species and its lectotype as designated by Cuatrecasas (1969) (Lebmann 5695, K!) to B. buxifolia (Lam.) Pers. Baccharis buxifolia and B. tricuneata differ from B. tenuicapitulata by e.g., campanulate (vs. cylindrical) capitula with more (e.g., female capitula with more than 20 , vs. less than 20) flowers, and apically long-dentate or fimbriate (vs. short-dentate) phyllaries (Table 1). Baccharis tenuicapitulata differs from all other species of Baccharis by the combination of subshrubby habit with a xylopodium, cylindrical, few-flowered capitula ( $<20$ flowers), small, acuminate leaves (usually less than $1 \mathrm{~cm}$ long), usually with small, acute teeth, apically acute, short-dentate phyllaries, non-elongating pappus of female flowers, and achenes with narrow or medium-sized intercostal epidermis cells and smooth cuticle.

\section{Baccharis tenuicapitulata Joch. Müll., sp. nov.}

TYPE: [Ecuador. Azuay:] Km 91 on Panamerican Highway N of Loja, $3^{\circ} 25^{\prime} \mathrm{S} 79^{\circ} 10^{\prime} \mathrm{W}$, dry scrub, 2900 
Table 1. Characters for separation of Baccharis tenuicapitulata, B. buxifolia, and B. tricuneata.

\begin{tabular}{|l|c|c|c|}
\hline & B. tenuicapitulata & B. buxifolia & B. tricuneata \\
\hline shape of capitula & cylindrical & campanulate & campanulate \\
\hline flower number in female capitula & $<20$ & 20 & $>20$ \\
\hline phyllary margins (apical part) & short-dentate & long-dentate or fimbriate & long-dentate or fimbriate \\
\hline achene cuticle & smooth & smooth & striate \\
\hline achenes, intercostal epidermal cells & $\begin{array}{c}\text { usually narrower than } 1 / 3 \text { of } \\
\text { width of rib sclerenchyma }\end{array}$ & $\begin{array}{c}\text { usually wider than } 1 / 3 \text { of } \\
\text { width of rib sclerenchyma }\end{array}$ & $\begin{array}{c}\text { usually narrower than } 1 / 3 \\
\text { of width of rib sclerenchyma }\end{array}$ \\
\hline
\end{tabular}

m, 5 May 1973, \&, L. Holm-Nielsen \& al. 5036 (holotype, NY!; isotypes, MO!, US!). Fig. 1.

$A$ aliis speciebus generis foliis parvis (minus quam $1 \mathrm{~cm}$ longis) acutidentatisque, capitulis tenuibus pauciflorisque cum involucro cylindraceo, pappo floribus femineis non crescento post augmine styli et achaeniis cum cellulis epidermalibus parvis vel intermediis cum cuticula laevi differt.

Dioecious subshrub with a xylopodium, 0.3-2 m tall; branching sympodial, erectopatent or erect; shoots mostly terminating in a capitulescence, sometimes proliferating, green or olive-green, strongly resinous like the leaves; older shoots brown, grooved. Leaves alternate, sessile, larger leaves 3.5-10(15) mm long, 1-3.5(6) mm wide, 1.7-4 times as long as wide, coriaceous, thick, narrowly obovate or oblanceolate, apex acuminate, base cuneate, margins in the distal half with to 3 short (rarely coarse), acute teeth on each side or (rarely) entire, seemingly 1 -veined from near the base, midrib adaxially flat or slightly raised, central vascular strand with strands of thick-walled sclerenchyma on both sides, connected by collenchymatous tissue with the epidermis of the abaxial side or both sides or not, with a marginal subepidermal layer of collenchymatous tissue; amphistomatic, palisade parenchyma on both sides; both leaf surfaces (and shoots) with tufts of 4-5-celled (except basal cell) flagellate hairs and biseriate glandular hairs; guard cells of stomata 45-110 $\mu \mathrm{m}$ long. Capitula (sub)sessile or pedunculate, borne in dense, semiglobose terminal racemes to $1 \mathrm{~cm}$ long or solitary in leaf axils of proliferating shoots; peduncles to $1.5 \mathrm{~mm}$ long, bracts absent. Male capitula 4.5-7 mm long; flowers 4-12; involucre cylindrical, $4-6 \mathrm{~mm}$ long, $1.5-2.5 \mathrm{~mm}$ wide; phyllaries 8-20 in 3-4(6) series; clinanthium flat or (rarely) slightly convex, glabrous, the ridges much shorter to slightly longer than scar diameter, at points of intersection forming a short, obtuse to (usually) long, acute apex; phyllaries thin to (more rarely) somewhat indurate, with acute apex, outermost phyllaries narrowly to broadly ovate, median phyllaries ovate or lanceolate, innermost phyllaries lanceolate, 2-3.5 times as long as the outermost, often with 2 or 3 parallel veins; all phyllaries light brown or strawcoloured, apically slightly to distinctly darker, margins narrowly scarious, short-dentate; phyllaries (the innermost often only subapically or only basally and subapically) abaxially with flagellate hairs and biseriate glandular hairs. Corolla $3.3-6 \mathrm{~mm}$ long, tube 2.2$4.2 \mathrm{~mm}$ long, throat $0-0.2 \mathrm{~mm}$ long, annular (if present), lobes $0.7-2 \mathrm{~mm}$ long, coiled at maturity, externally with biseriate hairs and glandular hairs on the throat and on the tube (downwards to near base or only in the distal two thirds). Anthers including apical appendage 1-1.3 times as long as the filaments; pollen grains $17-24 \mu \mathrm{m}$ in diameter. Style exceeding the corolla, the apex not or slightly capitate, not or slightly divided (less than halfway). Sterile ovary glabrous, with a few twin hairs or with other biseriate hairs. Pappus uniseriate (sometimes with some additional bristles), 3.7-5 mm long; bristles 15-33, apically twisted, slightly broadened, with short- to (rarely) longprotruding, erect or erectopatent cell ends. Female capitula 4.8-6.7 mm long; flowers 4-15; involucre 4.5$5.7 \mathrm{~mm}$ long, $1.5-2.5 \mathrm{~mm}$ wide, cylindrical; phyllaries $12-23$ in 4-5(7) series; clinanthium and phyllaries like those of male capitula. Corolla filiform, usually widened at base, $2.5-4 \mathrm{~mm}$ long, with 5 long apical teeth, with biseriate hairs over the whole length or glabrous near the base. Style 3-5.2 mm long, the branches 0.4-1.5 mm long. Achenes 1.2-1.7 mm long, 0.3-0.7 mm wide, straw-coloured or brown, glabrous, nearly cylindrical with a narrowed base, somewhat compressed laterally, with 8-11 strong longitudinal ribs; intercostal pericarp cells small or medium-sized in cross section, costal ones slightly to much smaller; pericarp much thicker than the testa epidermis, without papillae, cuticle smooth; ribs with thick sclerenchyma bundles, fibre walls as thick as or thicker than lumen diameter; epidermal cells of the testa with moderately evenly thickened outer walls, testa with narrowly rectangular to quadrangular crystal plates 6$20 \mu \mathrm{m}$ long. Pappus in several series, at achene matu- 


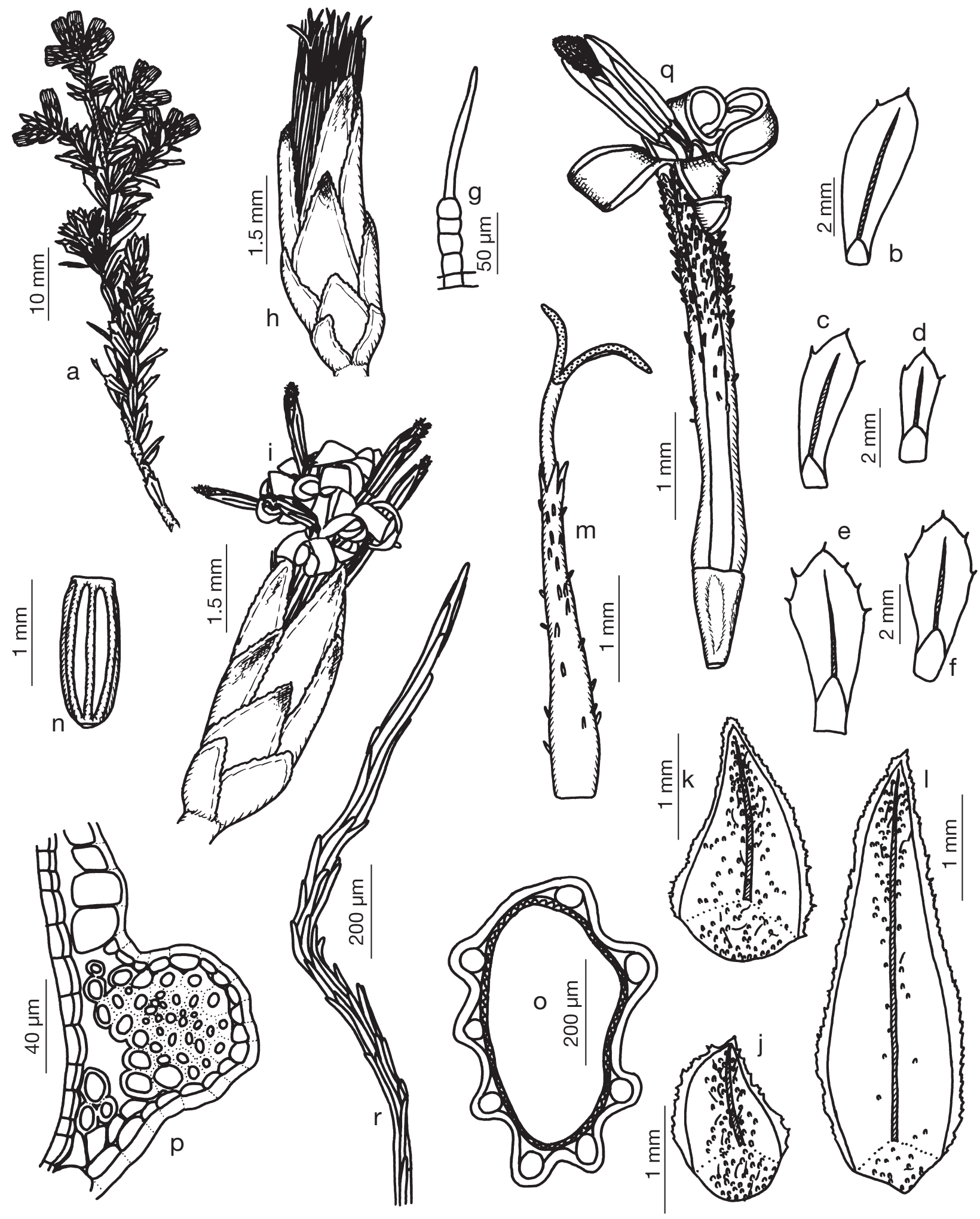

Fig. 1. Baccharis tenuicapitulata: $\mathbf{a}$, branch with female capitula; b-f, leaves; $\mathbf{g}$, flagellate hair (from leaf); $\mathbf{h}$, female capitulum; i, male capitulum; $\mathbf{j}$-l, phyllaries of female capitulum (outer to inner); $\mathbf{m}$, female flower; $\mathbf{n}$, achene; $\mathbf{o}$, achene in cross section, showing pericarp and testa epidermis; $\mathbf{p}$, detail of "O" (rib); q, male flower; $\mathbf{r}$, apex of pappus bristle from male flower [a, Holm-Nielsen \& al. 5036 (MO); b, e, f, i, q, Lewis \& Klitgaard 3530 (AAU); c, d, h, n-p, Ellemann 66930 (AAU); g, j-m, Camp E4132 (BR); r, Camp E4132 (B)]. 
rity not elongated, $3-5 \mathrm{~mm}$ long, about as long to much shorter than the style; bristles 40-75, deciduous.

\section{Habitat and distribution}

Baccharis tenuicapitulata is endemic in the Andes of central and southern Ecuador between the southern border of Prov. Chimborazo and the Saraguro region of northern Prov. Loja. Western and eastern limits of distribution are the crests of the Western and the Eastern Cordilleras. The new species was collected in grassland and scrub from 2100 to $3200 \mathrm{~m}$.

Local names: chiquito yardan, guarmin yardan, mujer yardan (from labels of Ellemann 66930, Ellemann 91617, Ellemann 91624, and Prieto s.n.).

\section{Additional specimens examined}

ECUADOR. Azuay: Eastern Cordillera, between Oña and the Río Yacuambi, W slope, ô, Prieto 210 (K, MO, NY, UC); Valley of the Río Paute, between Paute and Cuenca, ô, Prieto s.n., Camp E2567 (NY). Between Oña and Urdaneta, ô, Holm-Nielsen 22781 (AAU). Km 85 on Panamerican Highway $\mathrm{N}$ of Loja, ô, HolmNielsen E al. 4776 (MO). Gima \& Nabón, ô, Jameson s.n. (K). 31 $\mathrm{km} \mathrm{S}$ of junction Cuenca-Girón-Pasaje on road to Loja, ô, Lewis E Klitgaard 3530 (US). Ca. $40 \mathrm{~km}$ from Cuenca en route to Loja, o, Maguire \& Maguire 44294 (NY). Azuay/Loja: Cuenca-Loja road, $12 \mathrm{~km} \mathrm{~S}$ of Oña and $24 \mathrm{~km} \mathrm{~N}$ of Saraguro, +9 , Luteyn $\mathcal{E}$ Romoleraux 14466 (MO, NY, US). Chimborazo/Cañar: Near Pimo,
오 ô, Camp E4132 (B, BR, NY). Loja: Jera, $10 \mathrm{~km}$ N of Saraguro, , Ellemann 66930 (AAU); idem, Ellemann 91617 (AAU); idem, Ellemann 91624 (AAU). Saraguro, ca. $50 \mathrm{~km} \mathrm{~N} \mathrm{Loja,} \mathrm{ô,} \mathrm{Espinosa}$ 1368 (NY). Panamerican Highway between Tablón de Oña and Urdaneta, o , Harling 25631 (A). Cantón Saraguro, carretera Saraguro-Tenta, + ô, Jaramillo 7303 (GB).

\section{Acknowledgments}

The curators of the herbaria A, AAU, B, BR, GB, K, MO, NY, UC, and US provided loans of herbarium specimens of the new species. Pilar Catalán reviewed the Spanish version of the abstract. Michael Dillon and John Pruski made helpful comments on the manuscript.

\section{References}

Cuatrecasas, J. 1969. Notas adicionales, taxonómicas y corológicas sobre Baccharis. Revista de la Academia Colombiana de Ciencias Exactas, Físicas y Naturales 13: 201-226.

Jørgensen, P.M. 1999. Baccharis. In: Jørgensen, P.M. \& LeónYánez, S. (eds.), Catalogue of the vascular plants of Ecuador. Monographs in Systematic Botany from the Missouri Botanical Garden 75: 267-270.

Müller, J. 2006. Systematics of Baccharis (Compositae-Astereae) in Bolivia, including an overview of the genus. Systematic Botany Monographs 76: 1-341.

Asociate Editor: I. Álvarez Received: 5-V-2007 Accepted: 19-X-2007 